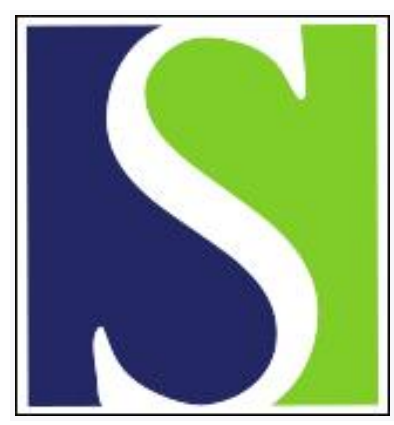

Scand J Work Environ Health 1980;6(4):274-282

https://doi.org/10.5271/sjweh.2607

Issue date: Dec 1980

Occupationally induced stress, strain and peak loads as related to age.

by Ilmarinen J, Rutenfranz J

Key terms: age; heart rate; occupational stress; occupationally induced stress; oxygen consumption; peak load; relative aerobic strain; relative strain; strain; stress; work content

This article in PubMed: www.ncbi.nlm.nih.gov/pubmed/7233116

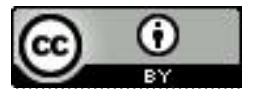




\title{
Occupationally induced stress, strain and peak loads as related to age
}

\author{
by Juhani IImarinen, PhD, ' Joseph Rutenfranz, MD, PhD ${ }^{2}$
}

\begin{abstract}
ILMARINEN J, RUTENFRANZ J. Occupationally induced stress, strain and peak loads as related to age. Scand $j$ work environ health 6 (1980) 274-282. From six different types of work 120 men, aged $23-60$ a, were classified according to the Ergonomic Job Description Questionnaire into four groups representing specific work content (producing forces, coordinating motor and sensory functions, converting information into reactions, and producing information). Work stress was assessed with measurements of oxygen consumption ( $\mathrm{VO}_{2}$ ) and with the registration of the minutes spent at different stress levels. Relative aerobic strain (RAS) was defined as the $\mathrm{VO}_{2}$ during work as the percentage of VOamax. Strain was measured with continuous recordings of heart rate during the workday. Peak loads were evaluated according to the relative number of. minutes above the heart rate levels of 130,150 and 170 beats $/ \mathrm{min}$. The VO2 during work was virtually identical in the age groups $<35,35-50$ and $>50$ a. The RAS tended to increase with age due to the decrease in VOmax. The strain remained practically the same in all the age groups. In the group "coordinating motor and sensory functions" strain tended to increase with age. Peak loads over 150 beats $/ \mathrm{min}$ were not rare for the older subjects. The results suggest that stress and strain during work remain practically the same as age increases. The RAS, however, tends to increase with age within groups doing mainly physical work and with exposures to peak loads.
\end{abstract}

Key terms: heart rate, oxygen consumption, relative aerobic strain, relative strain, work content.

Because physical work capacity and neuromuscular coordination decrease with age, some safety margins for daily work have been suggested. According to the World Health Organization, eg, oxygen consumption $\left(\mathrm{VO}_{2}\right)$ should not exceed $40-50 \%$ of the maximum ( $\mathrm{VO}_{2} \max$ ) during prolonged occupational work (3). No upper limits have been given for peak loads however. It has been suggested that peak loads of short duration can exceed $50 \%$ of the $\dot{\mathrm{V}} \mathrm{O}_{2} \max$ if the intermittent work intensity

1. Department of Physiology, Institute of Occupational Health, Helsinki, Finland.

2 Institute of Occupational Health, Dortmund, Federal Republic of Germany.

Reprint requests to: Dr Juhani Ilmarinen, Institute of Occupational Health, Laajaniityntie 1, SF-01620 Vantaa 62, Finland. has been low (1). Any effort exceeding the $\mathrm{VO}_{2} \max$ and lasting more than $4 \mathrm{~min}$ causes exhaustion and should be avoided (4).

Occupations with heavy physical work and/or high peak loads have decreased but not totally disappeared. The relative aerobic strain has been reported to be independent of age in construction work (2) but, on the other hand, to increase systematically with age after the age of 50 a in nonmotorized mail delivery (18). In a study on bank fishing (20) it was suggested that this heavy work need not be unsuitable for older fishermen if an effective job rotation is organized (20).

Our purpose was to study the relationship between strain and age in different groups of workers classified according to. their specific work content. 


\section{Material and methods}

The subjects were 120 men aged $23-60$ a from the following six types of work: construction industry $(N=19)$, iron and steel industry $(\mathrm{N}=23)$, chemical industry $(\mathrm{N}=17)$, retail trade (department store, $\mathrm{N}=14$ ), sales employees in the chemical industry $(\mathrm{N}=29)$, and government employees (research institute, $\mathrm{N}=18$ ). From each type the most typical jobs were selected. The 120 men were arranged into four groups (table 1) according to the specific work content. First the Ergonomic Job Description Questionnaire was used (22), and, after a cluster analysis (14), the subjects were classified into the following homogeneous groups: group 1: producing forces $(\mathrm{N}=21)$; group 2: coordinating motor and sensory functions $(\mathrm{N}=37)$; group 3: converting information into reaction $(\mathrm{N}=21)$; and group 4: transforming input-information into output-information $(N=30)$ and producing information $(\mathrm{N}=11)($ total $N=41)$
Within these groups the following three age groups were formed: $<35,35-50$ and $>50$ a. (The number of subjects in each age group can be found in table 4.)

To assess the work stress, the $\mathrm{VO}_{2}$ during work was measured. The gas samples were collected with a Kofranyi-Michaelis gas meter and analyzed for oxygen (Servomex) and carbon dioxide (Unor). Two typical steady or nonsteady state phases of work were selected for the measurements. The measurements were carried out with a sample of 40 subjects, mainly doing physical work in groups 1 and 2 .

The duration of different stress levels of work was registered with the diary method (11). A diary was kept by the subjects who did government and sales work; otherwise trained observers were used. The activities of the whole workday were classified into different stress levels adjusted to multiples of basal metabolic rates $(\mathrm{MET})$, eg, $\mathrm{S}$ (sitting) $=150$, SP (standing position) $=300,1$ (activity with minimum intensity) $=500,2$ (activity with medium

Table 1. Characteristics of the subjects.

\begin{tabular}{|c|c|c|c|c|c|c|}
\hline Work content & $\begin{array}{l}\text { Age } \\
\text { (a) }\end{array}$ & $\begin{array}{l}\text { Height } \\
(\mathrm{cm})\end{array}$ & $\begin{array}{l}\text { Weight } \\
(\mathrm{kg})\end{array}$ & $\begin{array}{l}\text { Fata } \\
(\%)\end{array}$ & $\begin{array}{c}\text { Maximal } \\
\text { oxygen } \\
\text { consump- } \\
\text { tion b } \\
(\mathrm{ml} / \mathrm{min} \times \\
\mathrm{kg})\end{array}$ & $\begin{array}{l}\text { Maximal } \\
\text { heart rateb } \\
\text { (beats/ } \\
\text { min) }\end{array}$ \\
\hline \multicolumn{7}{|c|}{ Producing forces $(N=21)$} \\
\hline $\begin{array}{l}\text { Mean } \\
\text { SD }\end{array}$ & $\begin{array}{r}38.8 \\
6.9\end{array}$ & $\begin{array}{r}176.6 \\
6.5\end{array}$ & $\begin{array}{l}83.2 \\
10.3\end{array}$ & $\begin{array}{r}23.6 \\
8.0\end{array}$ & $\begin{array}{r}37.5 \\
5.5\end{array}$ & $\begin{array}{r}180.6 \\
6.8\end{array}$ \\
\hline \multicolumn{7}{|c|}{$\begin{array}{l}\text { Coordinating motor and } \\
\text { sensory functions }(\mathrm{N}=37)\end{array}$} \\
\hline $\begin{array}{l}\text { Mean } \\
\text { SD }\end{array}$ & $\begin{array}{r}42.5 \\
8.3\end{array}$ & $\begin{array}{r}173.3 \\
5.2\end{array}$ & $\begin{array}{r}78.0 \\
8.2\end{array}$ & $\begin{array}{r}20.5 \\
4.1\end{array}$ & $\begin{array}{r}36.1 \\
5.2\end{array}$ & $\begin{array}{r}176.0 \\
6.6\end{array}$ \\
\hline \multicolumn{7}{|c|}{$\begin{array}{l}\text { Converting information into } \\
\text { reaction }(\mathrm{N}=21)\end{array}$} \\
\hline $\begin{array}{l}\text { Mean } \\
\text { SD }\end{array}$ & $\begin{array}{l}41.1 \\
10.4\end{array}$ & $\begin{array}{r}171.7 \\
4.7\end{array}$ & $\begin{array}{l}79.9 \\
10.2\end{array}$ & $\begin{array}{r}20.6 \\
8.9\end{array}$ & $\begin{array}{r}35.1 \\
5.1\end{array}$ & $\begin{array}{r}177.0 \\
8.3\end{array}$ \\
\hline \multicolumn{7}{|c|}{ Producing information $(N=41)$} \\
\hline $\begin{array}{l}\text { Mean } \\
S D\end{array}$ & $\begin{array}{r}41.3 \\
8.0\end{array}$ & $\begin{array}{r}176.6 \\
7.1\end{array}$ & $\begin{array}{r}81.2 \\
7.3\end{array}$ & $\begin{array}{r}23.0 \\
5.6\end{array}$ & $\begin{array}{r}37.6 \\
6.0\end{array}$ & $\begin{array}{r}177.0 \\
6.4\end{array}$ \\
\hline \multicolumn{7}{|c|}{ All groups $(N=120)$} \\
\hline $\begin{array}{l}\text { Mean } \\
\text { SD }\end{array}$ & $\begin{array}{r}41.2 \\
8.4\end{array}$ & $\begin{array}{r}174.7 \\
6.3\end{array}$ & $\begin{array}{r}80.3 \\
8.8\end{array}$ & $\begin{array}{r}21.9 \\
6.4\end{array}$ & $\begin{array}{r}36.7 \\
5.5\end{array}$ & $\begin{array}{r}177.3 \\
7.0\end{array}$ \\
\hline
\end{tabular}

a Predicted according to triceps and scapula skinfolds (12).

b Predicted (see the methods section). 
intensity) $=800$ and 3 (activity with high intensity) $=1,000 \%$ of the MET (24). The absolute and relative number of minutes at each stress level was assessed.

To assess the strain, we recorded the heart rate continuously over the whole workday with a small portable cardiocorder (23). The mean heart rate (HRmean), the mean minimum heart rate (HRmin), and the mean maximum heart rate (HRmax) during work, as well as the absolute and relative number of minutes in different heart rate classes, were calculated.
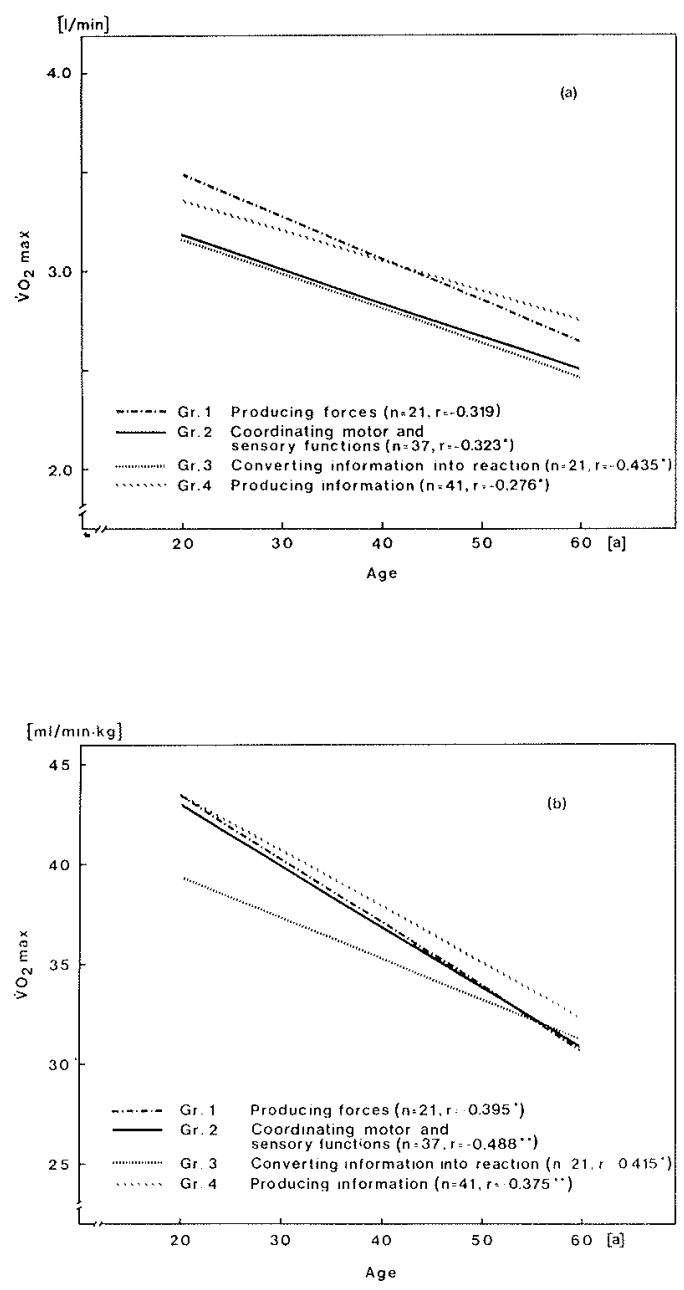

Fig 1. Predicted maximal oxygen consumption (VO2max) in (a) liters per minute and (b) milliliters per minute $\times$ kilograms as related to age in the groups classified according to specific work content.
To assess the relative strain, we calculated the HRmean as the percentage of heart rate range $(\% \mathrm{HRR})$ and as the percentage of individual maximal heart rate $(\%$ HRmax $)$. The heart rate range was defined as the difference between resting and maximal heart rate. Standard table values for resting and maximal heart rates adjusted for age were used, but, when lower resting and/or higher maximal values than standard values were recorded, they were used for the analysis.

The relative aerobic strain (RAS) was defined as $\mathrm{VO}_{2}$ during work as the percentage of the individual $\mathrm{VO}_{2} \max$. To assess the $\mathrm{VO}_{2} \max$, a submaximal test on a magnetically braked ergometer was used (17). The work load was continually increased up to $85 \%$ of the age-predicted HRmax. The $\mathrm{VO}_{2} \max$ was predicted (15) from $W_{170}$.

The difference in the stress and strain variables between the three age groups were tested with the Kruskal-Wallis oneway analysis of variance. Otherwise linear regression was used. The significances were assessed with two-tailed tests.

The $95 \%$ confidence curves for HRmean and RAS were calculated according to Armitage (5).

\section{Results}

The characteristics of the subjects, arranged into four homogeneous groups according to work content, are given in table 1. Group 1 ("producing forces"), which involved mainly heavy physical work, included the following jobs: bricklayer, carpenter, concrete reinforcement worker, and smelter. Group 2, "coordinating motor and sensory functions," consisted of iron workers, switchmen, workers in machine shops, and butchers. Group 3, "converting information into reactions," covered such jobs as crane operator, foreman, watchman, and sales clerk. Group 4, "producing information," was a combination of office employees, government employees, research assistants, and scientists. No statistically significant differences in the physiological characteristics of these four groups were found (table 1). 
Table 2. Oxygen consumption a $\left(\mathrm{V}_{2}\right)$ of different work contents.

\begin{tabular}{|c|c|c|c|c|c|}
\hline & \multicolumn{4}{|c|}{ Work content } & \multirow[b]{2}{*}{$\begin{array}{c}\text { All } \\
\text { groups }\end{array}$} \\
\hline & $\begin{array}{l}\text { Producing } \\
\text { forces }\end{array}$ & $\begin{array}{l}\text { Coordinating } \\
\text { motor and } \\
\text { sensory } \\
\text { functions }\end{array}$ & $\begin{array}{l}\text { Converting } \\
\text { information } \\
\text { into reaction }\end{array}$ & $\begin{array}{l}\text { Producting } \\
\text { information }\end{array}$ & \\
\hline \multicolumn{6}{|l|}{$\mathrm{VO}_{2}(1 / \mathrm{min})$} \\
\hline Mean & 1.31 & 0.91 & 1.03 & 0.50 & 1.08 \\
\hline $\mathrm{SD}$ & 0.31 & 0.19 & 0.30 & 0.04 & 0.37 \\
\hline $\begin{array}{l}\text { Number of } \\
\text { subjects }\end{array}$ & 20 & 13 & 3 & 4 & 40 \\
\hline
\end{tabular}

a Based on double measurements of each group.

\section{Maximal oxygen consumption}

The predicted $\mathrm{VO}_{2}$ max decreased with age in all four groups (fig 1). The decrease in $\mathrm{VO}_{2}$ max related to the body weight was larger than when measured only in liters per minute. From ages 20 to 60 a the mean decrease in $\mathrm{VO}_{2} \max$ was $26 \%$ when determined as milliliters per minute $x$ body weight $(\mathrm{kg})$ and $21 \%$ when measured as liters per minute. The corresponding $\mathrm{VO}_{2} \max$ values of group 1 were 29 and $24 \%$, respectively. This group showed the greatest decrease for both values.

\section{Stress at work}

The mean $\mathrm{VO}_{2}$ during work varied between 0.91 and $1.31 \mathrm{l} / \mathrm{min}$ in the groups (groups 1-3) doing physical work, while that of the sedentary group (group 4) was $0.50 \mathrm{l} / \mathrm{min}$ (table 2). The mean aerobic stress was highest in group 1 and at about the same level in groups 2 and 3 . Within the work groups the $\mathrm{VO}_{2}$ was at the same level for the three age groups. A comparison of all subjects in the three age groups showed that the two younger groups had about the same mean $\mathrm{VO}_{2}$, while that of the oldest group was somewhat higher (table 3). The absolute aerobic stress was not however statistically different between the age groups; this finding demonstrates that the $\mathrm{VO}_{2}$ during actual work remained in this sample at practically the same level as age increased.

The cumulative distribution of minutes at different stress levels showed only small differences between the age groups. The differences were more pronounced at a low rather than at a high stress level, as
Table 3. Oxygen consumption a $\left(\mathrm{V}_{2}\right)$ in three age groups at work.

\begin{tabular}{lccc}
\hline & \multicolumn{3}{c}{ Age group (a) } \\
\cline { 2 - 4 } & $<35$ & $35-50$ & $>50$ \\
\cline { 2 - 4 } & & & \\
VO $(1 / \mathrm{min})$ & 1.01 & 1.08 & 1.24 \\
$\quad$ Mean & 0.43 & 0.37 & 0.13 \\
SD & 12 & 23 & 5 \\
Number of & & & 5 \\
subjects & 12 & \\
\hline
\end{tabular}

a Based on double measurements of each age group.

shown for group 1 in fig 2 a. Characteristic of group 1 was that the oldest group still worked above a stress level of $500 \%$ MET for about $5 \%$ of the workday.

The distribution of minutes in group 2 was markedly different from that in group 1; the cumulative curve was shifted to the left, to a lower stress level. The younger groups worked for a shorter period than the oldest group at the stress level of $300 \%$ MEET (fig $2 \mathrm{~b}$ ).

Groups 3 and 4 had different characteristics than group 2 at a low stress level. They spent about $60-70 \%$ of their work time sitting and standing (150\%MET), which was more than double the time spent in such activities in group 2. A stress level of $300 \%$ IVET was typical for groups 3 and 4. Characteristic of all the work groups was that above a stress level of $150 \%$ MET the distribution of minutes was similar in all three age groups. In summary, the stress at work was not significantly different between the age groups in this study. 

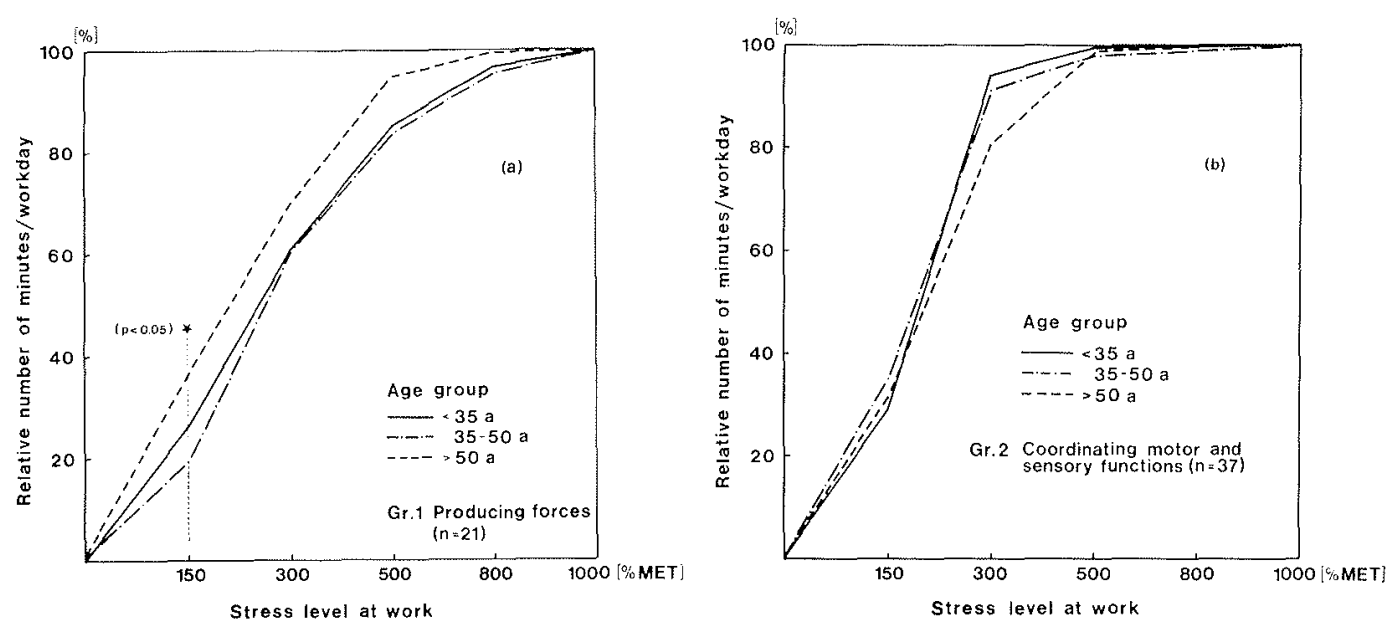

Fig 2. Cumulative distribution of minutes $(\%)$ at different stress levels during a workday of three age groups within (a) group 1 and (b) group 2. In group 1 the difference between the three age groups at a stress level of $150 \%$ MET (sitting and standing) was significant at the $5 \%$ level. $(100 \%$ MET $=$ basal metabolic rate $)$.
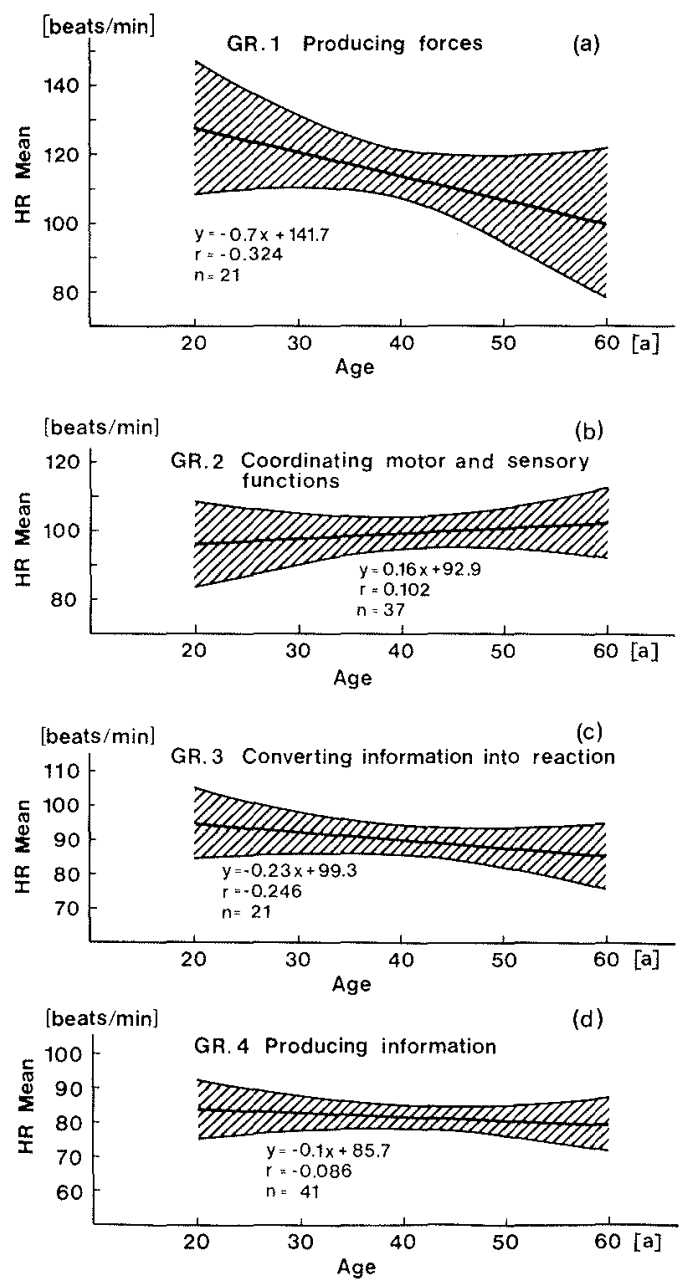

\section{Relative aerobic strain}

The relative aerobic strain (RAS) increased with age in all groups doing mainly physical work (groups 1-3). The RAS varied from 36 to $50 \%$ in group 1 between the ages of $20-60$ a (fig 3 a). The level of RAS in group 1 was systematically higher, but the increase with age was smaller than in group 2 or 3.

The RAS in group 2 demonstrated a marked difference with age; it was estimated to increase from resting level up to $47 \%$ at an age of 60 a. Also the confidence range was large (fig $3 \mathrm{~b}$ ).

The regression of group $3(\mathrm{r}=0.575)$ increased in parallel to that of group 2 and reached, at age 50, about the same level as that of group 2. The increase in RAS with age was not however statistically significant for groups 1,2 and 3 .

In contrast to the other groups, group 4 , sedentary workers, showed a decrease in RAS with age $(r=-0.578)$. With respect to all subjects, the RAS increased, but insignificantly, with age $(r=0.300)$.

Fig 3. Regression line and $95 \%$ confidence limits of mean heart rate (HR) during work and age in (a) group 1 , (b) group 2 , (c) group 3 , and (d) group 4. 
Strain at work

The HRmean and age showed some characteristic differences between the work groups (fig $4 \mathrm{a}-\mathrm{d}$ ). The HRmean decreased with age in groups 1 and 3 . It was practically unchanged in group 4 but tended to increase with age in group 2. The largest decrease was demonstrated for group 1 $(\mathrm{r}=-0.324)$. The upper and lower $95 \%$ confidence limits in fig 4 show the range of HRmean with age, which was, in general, larger in groups $1-3$, which did physical rather than mental work.

Group 2, which did mainly sensorimotor work tasks, showed an increasing tendency for HRmean with age $(r=0.102)$. At an older age their strain was at about the same level as that of the older members of group 1. When all the groups were taken into consideration, however, the changes in HRmean were not statistically significant. The HRmin and HRmax during work changed in a way similar to that of HRmean with age. In group 3, processing information into reactions, the HRmin decreased significantly with age $(r=-0.402$, $\mathrm{p}<0.05)$.

The results of relative strain $(\% \mathrm{HRR} \&$ $\%$ HRmax) demonstrated some characteristic differences between the work groups (table 4). In group 1 all the age groups had a mean relative strain close to $40 \% \mathrm{HRR}$. It dropped systematically to about $30 \%$ HRR in group 2 and further to about $20 \%$ HRR in group 3 . The difference was smallest between groups 3 and 4, the latter having the lowest relative strain, about $16 \%$ HRR. Within groups 1,3 and 4 the relative strain was practically the same in the three age groups. In group 2, however, the \%HRR increased from 25.3 to 31.5 and the \%HRmax from 52.9 to 60.7 from the youngest to the oldest group. When all of the subjects were taken into consideration, the relative strain remained at practically the same level in the three age groups: $\% \mathrm{HRR}$ varied on an average only from 24.9 to 26.2 and \% $\%$ HRmax from 52.4 to 56.3 .

The cumulative distribution of minutes at different heart rate levels also illustrated only small differences between the age groups. Generally, the oldest age group had more minutes at the lower heart rate levels than the younger groups. In groups 1,3 and 4 the differences were ob- served mainly at a heart rate level below 90 beats $/ \mathrm{min}$. In contrast in group 2 the oldest group had about $10 \%$ more minutes at the heart rate level of $101-130$ beats/ min than the youngest group. The differences between the age groups were not statistically significant however. In summary, strain was more related to work content than to age. The differences between the age groups were small and insignificant. Contrary to other groups, group 2 showed an increasing tendency towards strain with age.

\section{Peak loads}

The relative number of minutes above the three heart rate levels of 130,150 , and 170 beats $/ \mathrm{min}$ are given for the age and the work groups in table 5. Among the subjects doing heavy work (group 1) the duration of strain, 130 beats $/ \mathrm{min}$, was the
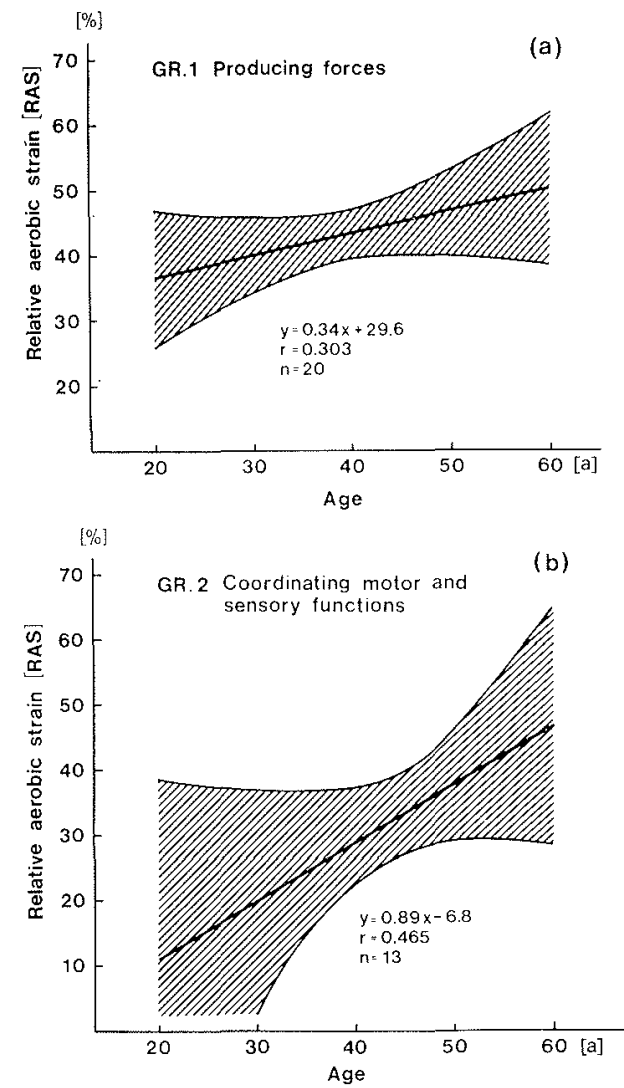

Fig 4. Regression line and $95 \%$ confidence limits of relative aerobic strain during work and age in (a) group 1 and (b) group 2. 
Table 4. Relative strain during work expressed as the percentage of heart rate range $(\% \mathrm{HRR})$ and maximal heart rate $(\% \mathrm{HRmax})$ according to groups of age and work content.

\begin{tabular}{|c|c|c|c|c|c|c|c|c|c|c|}
\hline \multirow{2}{*}{$\begin{array}{l}\text { Age group } \\
\text { (a) }\end{array}$} & \multicolumn{2}{|c|}{$\begin{array}{l}\text { Producing } \\
\text { forces }\end{array}$} & \multicolumn{2}{|c|}{$\begin{array}{l}\text { Coordinating } \\
\text { motor and } \\
\text { sensory } \\
\text { functions }\end{array}$} & \multicolumn{2}{|c|}{$\begin{array}{l}\text { Converting } \\
\text { information } \\
\text { into reaction }\end{array}$} & \multicolumn{2}{|c|}{$\begin{array}{l}\text { Producing } \\
\text { information }\end{array}$} & \multicolumn{2}{|c|}{ All groups } \\
\hline & $\begin{array}{l}\text { HRR } \\
(\%)\end{array}$ & $\underset{(\%)}{\operatorname{HRmax}}$ & $\begin{array}{r}\text { HRR } \\
(\%)\end{array}$ & $\begin{array}{c}\text { HRmax } \\
(\%)\end{array}$ & $\begin{array}{l}\text { HRR } \\
(\%)\end{array}$ & $\begin{array}{c}\text { HRmax } \\
(\%)\end{array}$ & $\begin{array}{c}\text { HRR } \\
(\%)\end{array}$ & $\begin{array}{c}\text { HRmax } \\
(\%)\end{array}$ & $\begin{array}{r}\text { HRR } \\
(\% / 0)\end{array}$ & $\underset{(\%)}{\operatorname{HRmax}}$ \\
\hline \multicolumn{11}{|l|}{$<35$} \\
\hline Mean & 44.7 & 65.7 & 25.3 & 52.9 & 23.0 & 51.2 & 16.1 & 46.1 & 26.0 & 53.1 \\
\hline SD & 13.3 & 8.1 & 5.9 & 3.9 & 5.1 & 4.9 & 4.1 & 3.8 & 12.6 & 8.6 \\
\hline$N$ & \multicolumn{2}{|c|}{6} & \multicolumn{2}{|c|}{8} & \multicolumn{2}{|c|}{6} & \multicolumn{2}{|r|}{9} & \multicolumn{2}{|c|}{29} \\
\hline \multicolumn{11}{|l|}{$35-50$} \\
\hline Mean & 38.6 & 61.8 & 29.6 & 57.0 & 19.7 & 49.1 & 16.2 & 45.1 & 24.9 & 52.4 \\
\hline $\mathrm{SD}$ & 12.1 & 7.5 & 12.1 & 8.4 & 8.3 & 5.8 & 5.6 & 5.9 & 12.6 & 9.5 \\
\hline$N$ & \multicolumn{2}{|c|}{12} & \multicolumn{2}{|c|}{23} & \multicolumn{2}{|c|}{11} & \multicolumn{2}{|c|}{25} & \multicolumn{2}{|c|}{71} \\
\hline \multirow{4}{*}{$\begin{array}{l}>50 \\
\text { Mean } \\
S D \\
N\end{array}$} & & & & & & & & & & \\
\hline & 40.5 & 65.6 & 31.5 & 60.7 & 24.4 & 54.7 & 16.6 & 49.5 & 26.2 & 56.3 \\
\hline & 12.7 & 7.3 & 14.7 & 8.7 & 6.0 & 3.3 & 4.0 & 5.3 & 12.7 & 8.5 \\
\hline & \multicolumn{2}{|c|}{3} & \multicolumn{2}{|r|}{6} & \multicolumn{2}{|r|}{4} & \multicolumn{2}{|r|}{7} & \multicolumn{2}{|c|}{20} \\
\hline \multicolumn{11}{|l|}{ All } \\
\hline Mean & 40.6 & 63.4 & 29.0 & 56.7 & 21.5 & 50.8 & 16.3 & 46.1 & 25.4 & 53.2 \\
\hline$S D$ & 12.2 & 7.7 & 11.4 & 7.9 & 7.1 & 5.4 & 5.0 & 5.5 & 12.5 & 9.2 \\
\hline $\mathrm{N}$ & \multicolumn{2}{|c|}{$21^{1.1}$} & \multicolumn{2}{|c|}{37} & \multicolumn{2}{|c|}{21} & \multicolumn{2}{|c|}{41} & \multicolumn{2}{|c|}{120} \\
\hline
\end{tabular}

Table 5. Mean relative number of minutes during one workday at a heart rate (HR) level of over 130,150 and 170 beats/min according to groups of age and work content.

\begin{tabular}{|c|c|c|c|c|c|}
\hline Work content & $\begin{array}{l}\text { Age group } \\
\text { (a) }\end{array}$ & $\begin{array}{l}\text { Number } \\
\text { of } \\
\text { subjects }\end{array}$ & $\begin{array}{l}\mathrm{HR}>130 \\
\text { beats } / \mathrm{min} \\
\quad(\%)\end{array}$ & $\begin{array}{l}H R>150 \\
\text { beats } / \mathrm{min} \\
(\%)\end{array}$ & $\begin{array}{l}\mathrm{HR}>170 \\
\text { beats } / \mathrm{min} \\
(\%)\end{array}$ \\
\hline Producing forces & $\begin{array}{r}<35 \\
35-50 \\
>50\end{array}$ & $\begin{array}{r}6 \\
12 \\
3\end{array}$ & $\begin{array}{l}31.7 \\
22.0 \\
17.1\end{array}$ & $\begin{array}{r}13.3 \\
5.3 \\
1.9\end{array}$ & $\begin{array}{l}1.5 \\
0.8 \\
0.1\end{array}$ \\
\hline $\begin{array}{l}\text { Coordinating motor and } \\
\text { sensory functions }\end{array}$ & $\begin{array}{r}<35 \\
35-50 \\
>50\end{array}$ & $\begin{array}{r}8 \\
23 \\
6\end{array}$ & $\begin{array}{l}0.9 \\
6.9 \\
7.6\end{array}$ & $\begin{array}{l}0.1 \\
0.7 \\
0.4\end{array}$ & - \\
\hline $\begin{array}{l}\text { Converting information into } \\
\text { reaction }\end{array}$ & $\begin{array}{r}<35 \\
35-50 \\
>50\end{array}$ & $\begin{array}{r}6 \\
11 \\
4\end{array}$ & $\begin{array}{l}1.0 \\
1.5 \\
-\end{array}$ & $\begin{array}{l}0.4 \\
0.2 \\
-\end{array}$ & $\frac{0.1}{-}$ \\
\hline Producing information & $\begin{array}{r}<35 \\
35-50 \\
>50\end{array}$ & $\begin{array}{r}9 \\
25 \\
7\end{array}$ & $\overline{0.4}$ & $\overline{0.1}$ & - \\
\hline
\end{tabular}

shortest in the oldest $(17.1 \%)$ and longest $(31.7 \%)$ in the youngest group. Calculated for an 8-h workday, the mean duration was 82 and $152 \mathrm{~min}$, respectively. Although a marked difference between the age groups existed, the results demonstrated that peak loads were not rare for older persons. Subjects over 50 worked $1.9 \%$ of the workday $(9 \mathrm{~min})$ with a heart rate of over 150 beats/min. Contrary to group 1 , group 2 showed that the oldest age group had more minutes over 130 beats $/ \mathrm{min}$ ( 36 $\mathrm{min})$ than the youngest group $(4 \mathrm{~min})$. In groups 3 and 4 peak loads were not common.

\section{Discussion}

The main result of this study was that occupationally induced strain remained at 
the same level in relation to capacity $(\%$ HRR and $\%$ HRmax $)$ or tended to increase $\left(\% \mathrm{VO}_{2} \max \right)$ with age in groups doing mainly physical work.

The decrease in $\mathrm{VO}_{2} \max$ with age among subjects doing heavy physical work (groups $1 \& 2$ ) is in agreement with the findings of other studies $(6,13)$. This result indicates that even hard physical work does not guarantee the maintenance of $\dot{V}$.max throughout the working age.

Because the occupational energy requirements did not decrease with age, the consequence was that the RAS tended to increase with age (fig 3). It should be emphasized, however, that although typical work tasks were selected for $\mathrm{VO}_{2}$ measurements, the values should be considered as actual stress values for heavy work and for peak loads rather than as mean values for an 8-h workday. On the other hand, the variables of strain covered a whole 8-h workday including breaks, and thus gave a more total estimation of the physical demands of the work. This difference explains why the variables of strain, eg, heart rates, were practically unchanged, while the RAS tended to increase with age.

An interesting finding was the increasing tendency of strain with age in group 2 (fig $4 \mathrm{~b}$, table 4). The work content of this group mainly involved coordinating motor and sensory functions, and the group consisted of subjects from the iron and steel industry, chemical industry, a department store, and from a machine shop. The analysis of their work profile showed that they were doing about $70 \%$ static and only $30 \%$ dynamic work tasks. About $30 \%$ of the time was spent in static postures, standing in a normal or bent position. They did arm work while sitting for about $25 \%$ of the time and arm work with holding, carrying, or lifting for about $15 \%$ of the workday (12). The static postures and work tasks seemed to lead to higher strain in the older than in the younger subjects. This result confirms the findings of McDermott et al (16) that static exercise in older men induces a significantly greater level of adrenaline than in younger subjects. In group 1, "producing forces," the HRmean at work tended to decrease with age. The same phenomenon was also found in construction work, for which it has been pointed out that younger men actually perform heavier work than older ones (2).

In our study the actual work load was about the same for the older and younger men, and therefore the RAS tended to increase with age. The decreased HRmean. in group 1 with age can be explained by the observations that older men had breaks of longer duration and they paused more often than the younger men doing heavy physical work.

The finding of practical importance was that both the older and younger men are exposed to peak loads. In spite of a rather spontaneously chosen level of stress and possibilities to modify the work during the 8-h period, the older men in this study were not able to avoid peak loads. Similar situations have been documented recently for different occupations $(9,20,21,25)$. In our study, during heavy phases of work, altogether 26 out of 40 subjects $(65 \%)$ had a $\mathrm{VO}_{2}$ that was higher than the $33 \%$ $\mathrm{VO}_{2} \max$ suggested as the upper limit for continuous work (4). For the present, however, no upper limits for peak loads of short duration ( $4 \mathrm{~min}$ ) have been set, but the $\mathrm{VO}_{2} \max$ has been given $(7,8,10)$. These suggestions allow that occupational peak loads of $1-2 \mathrm{~min}$ should be tolerated also at the (supra)maximal level, and, eg, a peak load of $10 \mathrm{~min}$ is still tolerable with a level of $90 \% \mathrm{VO}_{2} \max$. We cannot consider this as a margin for peak loads during daily work.

Because much of the work in industry involves varying degrees of static components, the $\mathrm{VO}_{2} \max$ should be measured for the work being done, as Petrofsky \& Lind (19) did for lifting tasks. They concluded that an average tolerable work load for lifting tasks was about $50 \pm 5 \% \quad \mathrm{VO}_{2} \max$; above this level heart rate and arterial lactates increase rapidly.

From the occupational health and safety point of view more attention should be paid to the study of the effects of peak loads in industry with the aim of keeping the RAS within reasonable limits with respect to age.

\section{Acknowledgments}

We wish to express our appreciation to Ms M Ahrens, Ms H Kylian, and Mr A Siuda of the Institute of Occupational 
Health, Dortmund, for their valuable assistance in the data collection and to $\mathrm{Mr}$ M Nurminen, LSc, Ms P Fahlström, and Ms T Martelin of the Institute of Occupational Health, Helsinki, who assisted with the statistical calculations.

\section{References}

1. Astrand I. Aerobic work capacity in men and women with special reference to age. Acta physiol scand 49 (1960): suppl 169.

2. Astrand I. Degree of strain during building work as related to individual aerobic work capacity. Ergonomics 10 (1967) 293303.

3. Andersen $K$, Rutenfranz $J$, Masironi $R$, Seliger $V$. Habitual physical activity and health. World Health Organization, Copenhagen 1978. (WHO regional publications: European series no 6).

4. Andersen KL, Shephard RJ, Denolin H, Varnauskas E, Masironi R. Fundamentals of exercise testing. World Health Organization, Geneva 1971.

5. Armitage P. Statistical methods in medical research. Blackwell Scientific Publications, Oxford 1971, pp 163-165.

6. Asmussen E, Poulsen E. Energy expenditure in light industry: Its relation to age, sex and aerobic capacity. Danish National Association for Infantile Paralysis, Hellerup, 1963. (Communications from the Testing and Observation Institute of the Danish National Association for Infantile Paralysis no 13).

7. Bink B. The physical working capacity in relation to working time and age. Ergonomics 5 (1962) 25-28.

8. Bonjer FH. Actual energy expenditure in relation to the physical working capacity. Ergonomics 5 (1962) 29-31.

9. Davies CTM, Brotherhood JR, Collins KJ, Dore C, Imms F, Musgrove $J$, Weiner JS. Energy expenditure and physiological performance of sudane cane cutters. $\mathrm{Br} j$ ind med 33 (1976): 3, 181-186.

10. Deivanayagam S, Ayoub MM. Prediction of endurance time for alternating workload tasks. Ergonomics 22 (1979): 3, 278-290.

11. Edholm OG. The assessment of habitual activity. In: Evang $K$, Andersen $K$, ed. Physical activity in health and disease. Universitets Förlaget, Oslo 1966, pp 187197.

12. Ilmarinen J. Beziehungen zwischen beruflicher und sportlicher körperlicher Aktivität und kardiopulmonaler Leistungsfähigkeit: Untersuchungen bei Männern mittleren Alters unter besonderer Berücksich- tigung prophylaktischer Aspekte der koronaren Durchblutungsstörungen. Diss., Köln 1978.

13. Jirak Z. Untersuchungsergebnisse über körperliche Leistungsfähigkeit der Industriepopulation in Ostrava. Med Sport 17 (1977) 5, 161-163.

14. Landau K, Luczak H, Rohmert W. Clusteranalytische Untersuchungen zum Arbeitswissenschaftlichen Frhebungsbogen zur Tätigkeitsanalyse - AET. Z Arbeitswiss 30 (1976) 31-39.

15. Lindemann $H$, Rutenfranz $J$, Mocellin $R$, Sbresny W. Methodische Untersuchung zur indirekten Bestimmung der maximalen 02-Aufnahme. Europ j appl physiol occup physiol 32 (1973) 25-53.

16. McDermott DJ, Stekiel WJ, Barboriak JJ, Kloth LC, Smith JJ. Effect of age on hemodynamic and metabolic response to static exercise. $J$ appl physiol 37 (1974): 6 , $923-926$

17. Müller EA, Olech KH. Eich-Kontrolle für das permanent-mangnetisch gebremste Fahrradergometer nach E. A. Müller. Arbeitswissenschaft 3 (1964) 176-177.

18. Oja P, Louhevaara V, Korhonen O. Age and sex as determinants of the relative aerobic strain of nonmotorized mail delivery. Scand $j$ work environ health 3 (1977) $225-233$

19. Petrofsky JS, Lind AR. Aging, isometric strength and endurance, and cardiovascular responses to static effort. $J$ appl physiol 38 (1975): $1,91-95$.

20. Rodahl K, Vokac Z. Work stress in longline bank fishing. Scand $j$ work environ. health 3 (1977) 154-159.

21. Rodahl K, Vokac $Z$, Fugelli $P$, Vaage $O$, Maehlum S. Circulatory strain, estimated energy output and catecholamine excretion in Norwegian coastal fishermen. Ergonomics 17 (1974) 585-602.

22. Rohmert W, Rutenfranz J. Arbeitswissenschaftliche Beurteilung der Belastung und Beanspruchung an industriellen Arbeitsplätzen, Hrsg.: Der Bundesminister für Arbeit und Sozialordnung. Referat Offentlichkeitsarbeit, Bonn 1975.

23. Rutenfranz J, Seliger V, Andersen KL, Ilmarinen $J$, Flöring $R$, Rutenfranz $M$, Klimmer F. Erfahrungen mit einem transportablen Gerät zur kontinuierlichen Registrierung der Herzfrequenz für Zeiten bis zu 24 Stunden. Europ j appl physiol occup physiol 36 (1977) $171-185$.

24. Seliger V, Trefny Z, Bartunkova S, Pauer M. The habitual activity and physical fitness of 12 year old boys. Acta paediat belg 28 (1974): suppl, 54-59.

25. Vokac Z, Rodahl K. Maximal aerobic power and circulatory strain in eskimo hunters in Greenland. Nordic Council, 1976, pp 16-30. (Arctic medical research report no 16$)$. 